Tables of Physical and Chemical Constants and some Mathematical Functions

Originally compiled by Dr. G. W. C. Kaye and Dr. T. H. Laby, now prepared under the direction of an Editorial Committee. Eleventh edition. Pp. vi +233. (London and New York : Longmans, Green and Co., Ltd., 1956.) 25s. net.

SINCE its inception in 1911, "Kaye and Laby" $S$ has been a household word arnong physicists and chemists, and though the link with the original authors is now severed-for Prof. Laby died during the printing of the tenth edition and Dr. Kaye while the ninth was being prepared-the tradition of the book is being well and truly maintained. This new eleventh edition is the work of an editorial board consisting of Prof. N. Feather (University of Edinburgh) as chairman, with Dr. H. Barrell (National Physical Laboratory, Teddington), Dr. E. A. Coulson (Chemical Research Laboratory, Teddington) and Mr. J. M. C. Scott (University of Cambridge) as the other members.

It is eight years since the tenth edition was published, and during this time both a great deal of new territory in the physical sciences has been discovered and also-and just as important-much of the ground that had been previously explored has been more thoroughly charted and consolidated. As a result, the compilation of new data and the revision of old material have been heavy, and thirty-eight contributors are listed as having had a hand in the present edition. Although much in detail has been altered, the essential features of "Kaye and Laby" remain as before. By a rigorous application to their task, the editors have succeeded in avoiding the obvious pitfall of allowing the volume to get out of hand in content and size, and, in fact, this edition is no larger than the provious one.

The book is divided into four eections, the first of which, on general physics, takes up nearly half the space (108 pages). Then follow the sections on chemistry (65 pages), atomic physics (35 pages) and four-figure mathematical tables (17 pages). Finally comes the index of seven pages ; this last-named is most important because, since there are no contents pages, the only way of finding a particular item rapidly is to look it up in the index.

Physical Properties of Wool Fibres and Fabrics (Wool Research, Volume 2.) Edited by H. Lemon. Pp. vi +234 . (Headingley, Leeds: Wool Industries Research Association, 1955.) $30 s$.

$\mathrm{T}$ HE understanding and development of tech. nological processes in the wool textile industry have been materially assisted in the last three decades by the Wool Industries Research Association. The present book is a summary of the research so far carried out at Torridon on the physical properties of wool fibres and fabrics. It does not describe work carried out to elucidate the structure of the fibre, but treats the measured physical properties of wool and relates them to its functional behaviour and to certain processes in textile technology.

Thus a large section of the book is given to a consideration of wool and water vapour relations, which have practical applications in such widely divergent fields as commercial testing for weight, the drying of fibre assemblies, and the design of clothing. This is followed by a section on the warmth of clothing which sets out the physics of the air-flow and heat transfer through fabrics, and also the relevance of the elastic properties of the fibre in maintaining the optimum fabric structures for warmth.

The mechanism of the water repellency of wool fabrics and feathers is discussed thoroughly-this has relevance in the design both of rainproof fabrics and of laboratory tests for their appraisal. The peculiar frictional properties of wool are discussed very fully - this is a very interesting chapter which summarizes all the work done in this field.

Physicists outside the textile industry will be interested in this chapter and that on the electrical properties of wool, in which fields notable contributions to basic physics have come from workers in technological foundations.

The selection of material is confined to those fields in which the Wool Industries Research Association has itself worked, and in some cases, in particular the chapter on elastic and plastic properties, is restricted to its own contributions. However, physicists and engineers interested in the properties of matter will find this book a stimulating introduction to some first-class work which has been published in many scattered journals.

The book is intended mainly for readers in industry and makes little demand upon mathematical skill. The presentation is generally clear and the book is very well illustrated.

W. J. OnIons

\section{Ciba Foundation Symposium}

Jointly with the Physiological Society and the British Pharmacological Society, on Histamine, in honour of Sir Henry Dale. Edited by G. E. W. Wolstenholme and Cecilia M. O'Connor. Pp. xvi +472. (London: J. and A. Churchill, Ltd., 1956.) 50s. net.

THIS volume, in fact, contains the proceedings of two symposia on histamine. The first symposium, which was held in public at the Welleome Institute, London, consisted mainly of formal papers which occupy about two-thirds of the book. The second, sponsored by the Ciba Foundation, was a private gathering in London of scientific men specially interested in histamine who met in honour of Sir Henry Dale and to talk about histamine. The recorded discussions of this symposium are a valuable feature of the book and repay careful study.

The subjects dealt with in the two symposia cover more or less the same ground. All the important advances of the past ten years are reviewed, and there is a wealth of bibliography. The new techniques, tracers and chromatography, in particular, have certainly yielded a plentiful harvest. Of outstanding interest are the new facts on the origin and fate of histamine in the body. For example, when isotopically labelled histidine is injected into an animal, some of it is converted into labelled histamine, presumably by decarboxylation. Histamine from this source forms a separate pool inside the cells, since it does not exchange with histamine injected into the body. It can, however, be released from the cells by a wide range of substances which contain basic groups. Once histamine has left the cell, it undergoes a rapid degradation and the various metabolites formed can be estimated in the urine. This is only one of many other fascinating contributions on the distribution of histamine in the body, its location in cells, the mode of its release by substances of known structure, its possible role in gastric secretion and on its curious association with heparin in mast cells.

For those who are interested in histamine, this is in every way an exceedingly useful and stimulating book. 